\title{
Geological engineering problems associated with tunnel construction in karst rock masses: The case of Gavarres tunnel (Spain)
}

\author{
S. Alija ${ }^{\mathrm{a}, 1}$, F.J. Torrijo ${ }^{\mathrm{b}, *}$, M. Quinta-Ferreira ${ }^{\mathrm{c}, 1}$ \\ a Geosciences Center, University of Coimbra, 3000-272 Coimbra, Portugal \\ b Department of Earth Engineering, Universidad Politécnica de Valencia, 46022 Valencia, Spain \\ c Department of Earth Sciences, Geosciences Center, University of Coimbra, 3000-272 Coimbra, Portugal
}

\section{A R T I C L E I N F O}

\section{Article history:}

Received 24 April 2012

Received in revised form 2 February 2013

Accepted 16 February 2013

Available online 4 March 2013

\section{Keywords:}

Tunnelling in karst

Karstified rock masses

Retrospective analysis

Gavarres tunnel

NATM

\begin{abstract}
A B S T R A C T
A representative example of the problems associated with the excavation and support of tunnels in karst ground is presented. It is a peculiar case in terms of heterogeneity and spatial distribution of zones of poor geotechnical quality, requiring the need to define, preferably in the study phases, adequate site investigation, suitable design procedures, efficient construction techniques and appropriate ground treatment. The difficulties associated with the instability of the karstified ground, and the presence of cavities, wholly or partially filled with soils of low cohesion, are discussed via retrospective analysis. The solutions adopted to solve the problems encountered during the tunnel construction enabled a systematic approach, useful for new construction projects in limestone terrains of medium to high karstification.
\end{abstract}

(c) 2013 Elsevier B.V. All rights reserved.

\section{Introduction}

The design and construction of tunnels in karst terrains is fraught with problems associated with the unexpected location, irregular geometry and unpredictable dimensions of the karst structures.

In a karstified terrain, prospection and regular testing campaigns should be supplemented with other techniques adapted to locate and anticipate the problematic zones. It must be taken into account that no site investigation technique is one hundred percent accurate, and therefore several techniques should be used, adapted to each specific situation, taking into consideration the budget for the work and the risks that can be assumed in the project.

A real case of a tunnel constructed in a karstified limestone ground is presented, the problems encountered are described and the proposed solutions are discussed. A systematic approach, as a knowledge tool for future work in similar situations, is presented.

\section{Geological framework}

From the geological point of view, the study area is located in the Les Gavarres region, which is included within the Catalan Transverse

\footnotetext{
* Corresponding author. Tel.: + 34963877582.

E-mail addresses: santiagoalija@gmail.com (S. Alija), fratorec@trr.upv.es

(F.J. Torrijo), mqf@dct.uc.pt (M. Quinta-Ferreira).

1 Tel: +351239860500
}

System, directly related with the Neogene depression of the Empordà (Agustí et al., 1994).

Les Gavarres region consists of a fringe of Palaeogene materials (mainly Eocene), arranged around a Hercynian rock massif, outcropping south of the study area. The age of these materials is prior to the Alpine Orogeny, as they have suffered deformation and fracturing during this tectonic phase. The series is dislocated in blocks, separated by fractures that lead to the uplifting of the massif. The general structure is a monocline arrangement, dipping mainly to Northeast (IGME, 1983, 1995). The geological formations affecting the tunnel are (Figure 1) the following:

- Barcons Sandstone Formation $\left(E_{A}\right)$. It is composed by glauconitic sandstone, medium to coarse grained, locally conglomeratic. The predominant colour is grey-yellowish or ochre. The grains are mainly of quartz and feldspar with a scarce clay matrix. It has calcareous cement and abundant bioclasts. At the base and top of the series, the layers are decimetric to metric, presenting a more massive appearance in the middle of the formation. The average sedimentation corresponds to a deposit in the frontal area of the delta, which is rather thick, but of limited extent. The age of the series is Eocene.

- Banyolas Limestone Formation $\left(E_{M}\right)$. This formation is composed of layers of limestone and marl, whose relative proportion varies throughout the series. They are of grey and bluish grey colours, and the layers have decimetric thickness. The carbonate content ranges from marly clay to limestone, affecting materials' strength, weatherability and the stability behaviour of the rockmass. Some spans of the series are mainly composed of hard clay and marls. The age of 

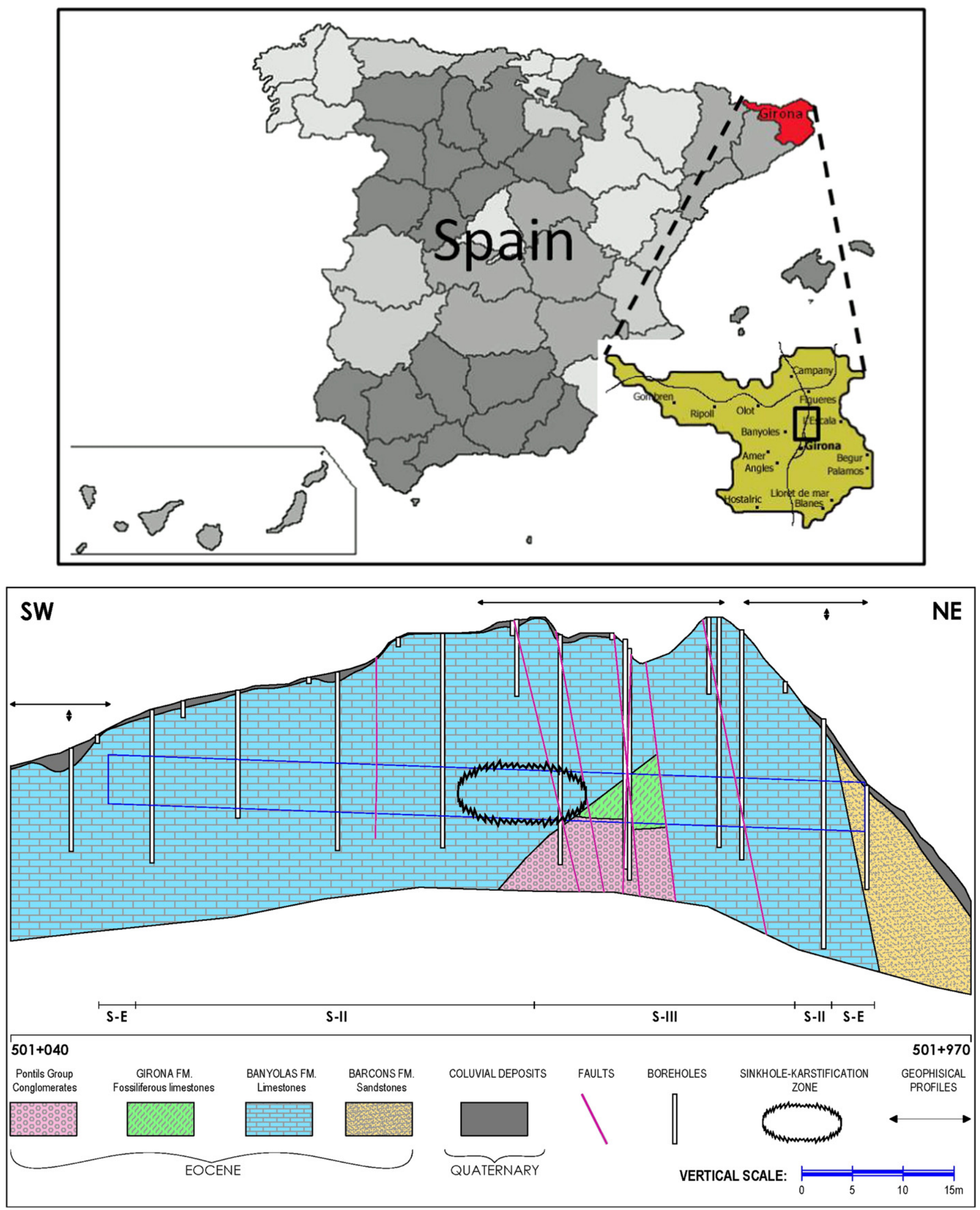

Fig. 1. Location map and geology profile along the Gavarres tunnel.

the series is Eocene. It is important to note that the Banyolas Limestone Formation is in concordance with the underlying Girona Fossiliferous Limestone Formation.
- Girona Fossiliferous Limestone Formation $\left(E_{C}\right)$. It is a fossiliferous limestone, presenting oolitic terms at the base. The predominant colour is ochre. It is rather recrystallized and arranged in layers of a wide range 
Table 1

Sieve analysis and consistency limits (Atterberg limits) of the soil materials of the Gavarres tunnel.

\begin{tabular}{|c|c|c|c|c|c|c|c|c|c|c|}
\hline \multirow[t]{2}{*}{ Geotechnical unit } & \multirow[t]{2}{*}{ Characteristics } & \multirow[t]{2}{*}{ Values } & \multirow{2}{*}{$\begin{array}{l}\text { Specific gravity } \\
\left(\mathrm{g} / \mathrm{cm}^{3}\right)\end{array}$} & \multirow{2}{*}{$\begin{array}{l}\text { Unit weight } \\
\left(\mathrm{g} / \mathrm{cm}^{3}\right)\end{array}$} & \multicolumn{3}{|c|}{ Atterberg limits } & \multicolumn{3}{|c|}{ Sieve analysis } \\
\hline & & & & & $\begin{array}{l}\text { Liquid limit } \\
(\%)\end{array}$ & $\begin{array}{l}\text { Plastic limit } \\
(\%)\end{array}$ & $\begin{array}{l}\text { Plasticity index } \\
(\%)\end{array}$ & $\begin{array}{l}\text { Gravel } \\
(\%)\end{array}$ & $\begin{array}{l}\text { Sand } \\
(\%)\end{array}$ & $\begin{array}{l}\text { Silt or clay } \\
(\%)\end{array}$ \\
\hline \multirow[t]{4}{*}{ Limestone and foam } & & Test number & 4 & 11 & 30 & 30 & 30 & 29 & 29 & 29 \\
\hline & Bedrock altered rock & Max & 2.67 & 2.06 & 38.00 & 21.00 & 18.00 & 64.00 & 38.00 & 98.00 \\
\hline & & Min & 1.76 & 1.54 & 23.40 & 12.40 & 7.90 & 0.00 & 2.00 & 25.00 \\
\hline & & Mean & 2.12 & 1.79 & 30.09 & 16.34 & 13.75 & 14.11 & 15.74 & 70.26 \\
\hline \multirow[t]{4}{*}{ Fault zone } & & Test number & 15 & 10 & 10 & 10 & 10 & 10 & 10 & 10 \\
\hline & Bedrock altered rock & Max & & 2.55 & 40.30 & 18.70 & 21.60 & 21.00 & 49.00 & 98.00 \\
\hline & & Min & & 1.71 & 26.80 & 13.00 & 11.90 & 0.00 & 1.00 & 30.00 \\
\hline & & Mean & & 2.03 & 33.31 & 16.34 & 16.97 & 3.60 & 10.80 & 85.60 \\
\hline
\end{tabular}

of thickness, from decimetric to metric. The environment of sedimentation corresponds to proximal marine environments of carbonate platform. The age of the series is Eocene.

- Pontils Group Conglomerates $\left(E_{C G}\right)$. This formation is constituted by conglomerates and red sandstones with clay layers. These deposits have fluvial origin. The age of the series is Lower Eocene, but may also include part of Palaeocene.

The boundary between the Les Gavarres region and the SW margin of the Ampurdán depression is marked by a fracture alignment oriented NW-SE, called Banyolas Fault or Camós-Celrá. This alignment is part of a system of fractures orientated predominantly NW-SE. They are normal faults related to quaternary volcanism and recent seismicity. This important regional fault intersects the line of the tunnel, corresponding to intense fracturing of the rock material.

\section{Geotechnical characteristics}

According to the geological cross section defined in the design, most of the tunnel would be excavated in the materials of the Banyolas Marl Formation (Figure 1) while the northern part is affected by the fault system associated with the Banyolas Fault or Camós-Celrá.

The two fundamental geotechnical units are described below. The results of the laboratory tests, from samples collected in the tunnel boreholes, are shown in Tables 1 and 2:

- Limestone and Marl Geotechnical Unit. This unit is entirely constituted by calcareous rocks of the Banyolas Limestone Formation $\left(E_{M}\right)$. The rock samples tested generally present medium to low strength, with a weathering grade, in the vicinity of the tunnel, ranging from III to $\mathrm{V}$ (according to ISRM, 1981). The seismic profiles carried out in the tunnel confirmed this data. The water table detected in the boreholes was located below the invert of the tunnel. The average densities (Table 1) and uniaxial compressive strength (Table 2) gave very scattered values, depending on the degree of weathering of the sample (Barton et al., 1974). During the site investigation programme, permeability tests revealed medium-low permeability terrains (González de Vallejo et al., 2002), around $1 \times 10^{-7} \mathrm{~m} / \mathrm{s}$. Considering the RQD values obtained in the borehole samples and the uniaxial compressive strength, a representative RMR value of 30 was estimated (class IV or Bad, Bieniawski, 1989).

- Fault Zone Geotechnical Unit ( $E_{M}$ very fractured). It is a highly fractured zone, where argillite, calcareous mylonite and marl have been identified. The rock weathering ranges from grade II to V (according to ISRM, 1981). Water levels were found at different heights, associated with fracture planes. Although most of the unit consists of highly fractured limestone and marl, from the Banyolas Limestone Formation, the presence of a small thickness of Girona Fossiliferous Limestone $\left(E_{C}\right)$ was also observed in boreholes as well as conglomerates and red sandstones of the Pontils Group ( $E_{\mathrm{CG}}$ ). Both formations present weathering grades of IV-V (according to ISRM, 1981). The permeability tests showed low to medium values, similar to those usually presented by fractured rock masses of limestone and dolomite $\left(1 \times 10^{-6} \mathrm{~m} / \mathrm{s}\right)$. Mainly based on the RQD values of the rock cores and on the uniaxial compressive strength values, an RMR value of 20 was estimated (class V or Very Poor, Bieniawski, 1989).

\section{Construction project}

The tunnel is part of the Madrid-French border high-speed railway line, and is located within the province of Girona (Figure 1). It is a double track tunnel having a total length of $758 \mathrm{~m}$ with a maximum overburden of $31 \mathrm{~m}$. The average altitude of the tunnel is $93.5 \mathrm{~m}$ above sea level.

The free section of the tunnel, defined in terms of health and comfort criteria, was $110 \mathrm{~m}^{2}$. The geometric characteristics of the tunnel's cross section were designed using a circular vault extending into the floor, without differentiating the gables (López, 1996).

Having in mind the characteristics of the in situ materials and the dimensions of the tunnel, it was considered that the mechanical excavation was the most suitable procedure and that blasting could be used in the unweathered limestone zones (Díaz, 1997).

Table 2

Strength parameters of the Gavarres tunnel obtained over rock cores tested in the laboratory.

\begin{tabular}{|c|c|c|c|c|c|c|c|}
\hline \multirow[t]{2}{*}{ Geotechnical unit } & \multirow[t]{2}{*}{ Characteristics } & \multirow[t]{2}{*}{ Values } & \multirow{2}{*}{$\begin{array}{l}\text { UCS } \\
\left(\mathrm{kg} / \mathrm{cm}^{2}\right)\end{array}$} & \multicolumn{2}{|l|}{ Triaxial test (CU) } & \multicolumn{2}{|c|}{ Direct shear test (CD) } \\
\hline & & & & $\begin{array}{l}\text { Effective cohesion } \\
\left(\mathrm{kg} / \mathrm{cm}^{2}\right)\end{array}$ & $\begin{array}{l}\text { Effective friction angle } \\
\left({ }^{\circ}\right)\end{array}$ & $\begin{array}{l}\text { Effective cohesion } \\
\left(\mathrm{kg} / \mathrm{cm}^{2}\right)\end{array}$ & $\begin{array}{l}\text { Effective friction angle } \\
\left({ }^{\circ}\right)\end{array}$ \\
\hline \multirow{4}{*}{ Limestone and foam } & & Test number & 18 & 4 & 4 & 1 & 1 \\
\hline & Bedrock altered rock & Max & 183.6 & 0.42 & 35.83 & 0.10 & 44.00 \\
\hline & & Min & 0.3 & 0.14 & 24.95 & 0.10 & 44.00 \\
\hline & & Mean & 26.03 & 0.24 & 31.12 & 0.10 & 44.00 \\
\hline \multirow[t]{4}{*}{ Fault Zone } & & Test number & & 1 & 1 & & \\
\hline & & Max & & 0.3 & 28 & & \\
\hline & & Min & & 0.3 & 28 & & \\
\hline & & Mean & & 0.3 & 28 & & \\
\hline
\end{tabular}


The design recommended the use of the New Austrian Tunnelling Method (NATM), since it could allow pre-support during tunnel advance, through mechanical pre-cutting.

The excavation phases used in the tunnel were as follows: one excavation phase in full section in the top heading, two excavation subphases in the bench and one excavation phase in the inverted vault.

In the design of the tunnel support, three section types were defined (Figure 1), ranging from the better quality terrains to the weakest (Hoek and Brown, 1980; Hoek et al., 1995):

- S-II: this section type applies to the weathered calcareous rocks of the Banyolas Limestone Formation. The excavation should be performed in advances of $1.0 \mathrm{~m}$ in the top heading, with primary support based on a $5 \mathrm{~cm}$ sealing of shotcrete with steel fibre, light steel ribs type TH-29 and shotcrete with steel fibre, $25 \mathrm{~cm}$ thick in total (excluding the $5 \mathrm{~cm}$ of sealing). The two sub-phases of the bench were implemented in $2.0 \mathrm{~m}$ spans extending the support of the top heading.

- S-III: was used for the fault zone unit. In this section type, the excavation would be done in advances of 0.5 to $1.0 \mathrm{~m}$ with support based on a $5 \mathrm{~cm}$ sealing of shotcrete with steel fibre, heavy steel ribs of type HEB-160 and shotcrete with steel fibre, $30 \mathrm{~cm}$ total thickness (excluding the $5 \mathrm{~cm}$ of sealing). The drilling of the bench would be done in two sub-phases, with advances from 1.0 to $2.0 \mathrm{~m}$ extending the support of the top heading.

- S-E: was the section type for the tunnel portals. It was characterised as type "heavy" as these zones were expected to be more weathered, decompressed due to the previous excavation of the portal slopes and presenting a rather thin overburden above the tunnel. The S-E section consisted of a heavy micropile umbrella, $20 \mathrm{~m}$ long and $150 \mathrm{~mm}$ in drilling diameter, spaced $0.5 \mathrm{~m}$ between axes and fitted with steel pipes, $110 \mathrm{~mm}$ of external diameter and $8 \mathrm{~mm}$ thick, filled with mortar. The excavation and support sequence for this section would be similar to S-III, with the difference that the steel ribs used below the umbrella would be type HEB- 180 .

All sections should have a concrete inverted vault with welded wire mesh $150 \times 150 \times 6 \mathrm{~mm}$.

A summary table with the support structures defined for the tunnel is presented in Table 3.

\section{Construction of the tunnel}

The construction of the Gavarres tunnel began by its south portal in limestone materials (Figure 1). First, the excavation and support of the portal slopes was carried out. The excavation was done using mechanical heavy duty rotating machines. During this early stage of excavation, the heterogeneity of the limestone rock mass was detected. The working face presented very weathered areas which are easy to excavate and, alternating with limestone, are very difficult to break mechanically.

Once at the tunnel crown level, a micropile umbrella was carried out, for the S-E section type (35 micropiles in total). During the implementation of these micropiles, the heterogeneity of the ground

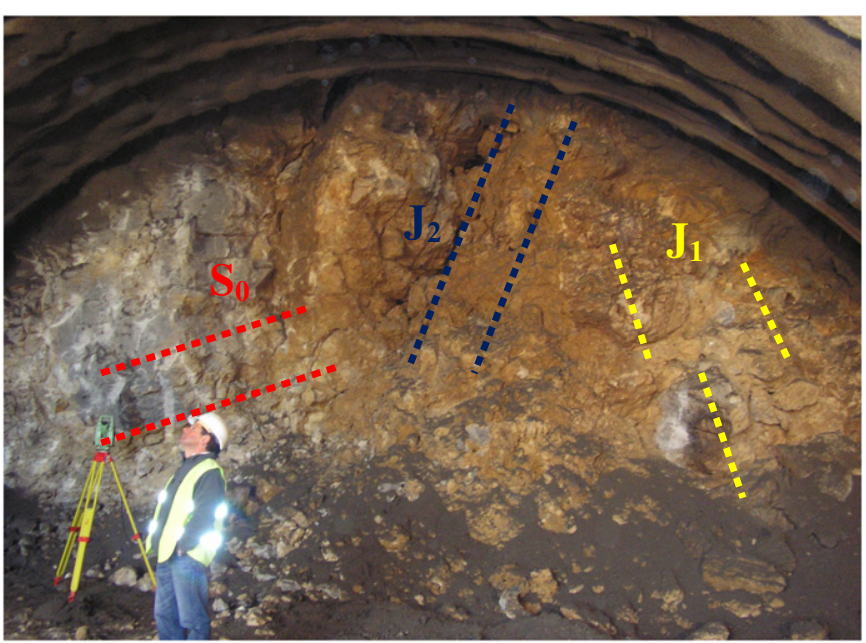

Fig. 2. Tunnel-working face view of section 19 with details of the stratification $\left(\mathrm{S}_{0}\right)$ and joints $\left(\mathrm{J}_{1}, \mathrm{~J}_{2}\right)$. Marl and limestone blocks, some broken, in a clay matrix.

continued to be revealed, since the implementation speed ranged from 1 to 4 micropiles per day. The drilling residues changed drastically from limestone fragments to a clay-like material.

According to the geotechnical characteristics of the ground during excavation and support, mainly associated with the karstification processes, different zones were considered along the tunnel (Alija, 2010):

- Portal Zone (sections 0-22). The excavation of the tunnel started with mechanical equipment, reaching an average progress speed of $4.7 \mathrm{~m} /$ day. In this zone, four sections of convergence were installed and eight engineering geology front maps were prepared. The ground materials were characterised as blocks of limestone and marl, sometimes broken, embedded in a clay matrix. The stratification was as follows:

- $S_{0}$ : oriented between 200/15 and 200/30 (dip direction/dip angle), with some continuity and some roughness. Between layers, openings of 5 to $10 \mathrm{~mm}$ were observed, filled with clay or even calcite.

Two families of joints were identified (Figure 2):

- $J_{1}$ : with an average orientation of $213 / 71$, spaced about $30 \mathrm{~cm}$, with some continuity and, when filled, it is with clay material.

- $J_{2}$ : with an average orientation of $124 / 70$, spaced from 20 to $60 \mathrm{~cm}$, very rough and usually closed.

These two families of joints and the stratification maintained their orientation all along the tunnel, but due to the heterogeneity of the rock mass, they were not found or distinguished on all of the fronts mapped.

According to the front reports, the average RMR value obtained for this area was 36, corresponding to a rock mass of class IV (poor grade). During the excavation and support operations, small falls of rock and clay occurred. In sections 2 and 3, the instabilities in the roof of the tunnel achieved $12 \mathrm{~m}^{3}$. Detachments were also

Table 3

Summary of the support structures proposed for the three section types of the Gavarres tunnel.

\begin{tabular}{|c|c|c|c|c|c|c|}
\hline Section type & Geotechnical unit & RMR & Excavation/pass & $\begin{array}{l}\text { Shotcrete with steel } \\
\text { fibre }(\mathrm{cm})\end{array}$ & Trusses & Special systems \\
\hline S-II & Limestone and loam & $30-45$ & $\begin{array}{l}\text { Top heading ( } 1 \text { phase) and bench } \\
\text { ( } 2 \text { phases) } 2 \mathrm{~m} \text { bench }\end{array}$ & $\begin{array}{l}5 \text { (sealing) }+25 \\
\mathrm{HM}-35\end{array}$ & $\begin{array}{l}\mathrm{TH}-29 / / \\
1-1.5 \mathrm{~m}\end{array}$ & $\begin{array}{l}\text { Elephant foot } \\
\text { Inverted foot }\end{array}$ \\
\hline S-III & Fault zone & $20-29$ & $\begin{array}{l}\text { Top heading ( } 1 \text { phase) and bench } \\
\text { ( } 2 \text { phases) } 2 \mathrm{~m} \text { bench }\end{array}$ & $\begin{array}{l}5 \text { (sealing) }+30 \\
\text { HM-35 }\end{array}$ & $\begin{array}{l}\text { HEB-160// } \\
0.5-1 \mathrm{~m}\end{array}$ & $\begin{array}{l}\text { Elephant foot } \\
\text { Inverted foot }\end{array}$ \\
\hline SE & $\begin{array}{l}\text { Outlets } \\
\text { Portals }\end{array}$ & $<19$ & $\begin{array}{l}\text { Top heading ( } 1 \text { phase) and bench } \\
\text { ( } 2 \text { phases) } 2 \mathrm{~m} \text { bench }\end{array}$ & $\begin{array}{l}5(\text { sealing })+30 \\
\mathrm{HM}-35\end{array}$ & $\begin{array}{l}\text { HEB- } 180 / / \\
0.5-1 \mathrm{~m}\end{array}$ & $\begin{array}{l}\text { Heavy micropile umbrellas } \\
\phi=150 \mathrm{~mm} \\
\text { Elephant foot } \\
\text { Inverted vault }\end{array}$ \\
\hline
\end{tabular}


produced on the right side of the roof and gable, of sections 13 and 14 , achieving $15 \mathrm{~m}^{3}$. Instabilities also occurred in the gable and right shoulder in sections 20 to 21 . These detachments showed the presence of small fragments of limestone embedded in a clay matrix. The large volume of fallen materials required its filling with concrete, using Bernold plates as lost formwork. Throughout this zone, a portal section type (S-E) was implemented.

- Zone 1 (sections 22-38). In this zone, heterogeneous tunnelworking faces appeared, composed of very compact marly limestone layers, and occasionally with clay or even calcite filling the spaces in the clay matrix. In the final metres of the zone wet spots in the clay were often found, and some karstification voids were identified (Anguita and Moreno, 1993). The advance speed in this zone slowed down to an average of $3.3 \mathrm{~m} /$ day, because very specific blasting was required to break up the hardest limestone materials. The rock mass appeared to have higher hardness than in the previous zone. Nine engineering geology front maps were prepared. The average RMR value was 43 , allowing a fair to good stability of the front, and the advance in passes of $1 \mathrm{~m}$ using mechanical excavation. The RMR values obtained in this section were compatible with the S-II support type. However, taking into account the heterogeneity of the fronts and the thin overburden, it was decided to use a conservative stance, and the support defined for S-III with passes of $1 \mathrm{~m}$ was installed. The accumulated strain denoted a clear evolution towards stabilization, reaching values under $5 \mathrm{~mm}$.

- Zone 2 (sections 38-91). Corresponds to $53 \mathrm{~m}$ with moderate karstification. Several instabilities occurred, composed of highly fractured marl-limestone rock fragments embedded in a clay matrix. The weathering grade of this zone ranges from III to IV (Figure 3).

The average advance speed of the excavation was slightly reduced to $3.18 \mathrm{~m} /$ day, due to the decrease in the geotechnical characteristics of the ground mass. The strength of the limestone fragments decreases from an average of $44 \mathrm{MPa}$ in Zone 1 to $34 \mathrm{MPa}$ in Zone 2. The materials observed in this zone were highly fragmented and the damp spots were a constant. The RMR values were in the range 25-35, corresponding to a poor quality rock mass of class IV, in which S-II or S-III support type could be installed. On site it was decided to maintain the S-III support. The convergence strain was generally lower than $4 \mathrm{~mm}$. Once passed Zone 1, steel ribs HEB-160 and $35 \mathrm{~cm}$ of shotcrete HM-35 (S-III) continued to be used for more $15 \mathrm{~m}$, until section 54 when rockfalls began to occur. This problem required the use of a pre-support system based on a light bolt umbrella ( $4 \mathrm{~m}$ long with an overlap of $2 \mathrm{~m}$ ) and packed with light beams (Figure 4).

Due to the increase in the number and size of the instabilities it was

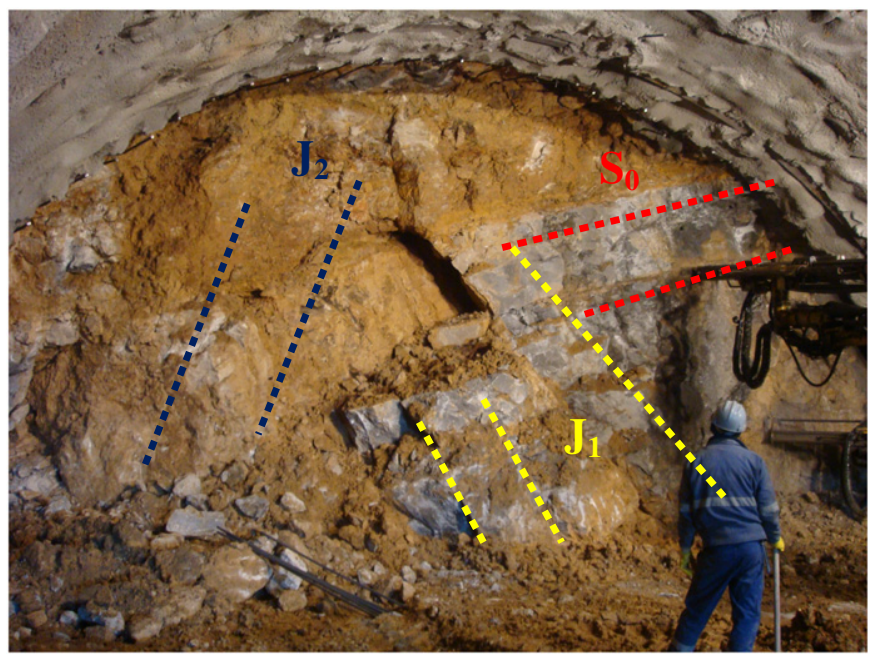

Fig. 3. Tunnel-working faces with weathering degree III in Zone 2 (section 61). Highly fractured marl-limestone rock fragments embedded in a clay matrix.

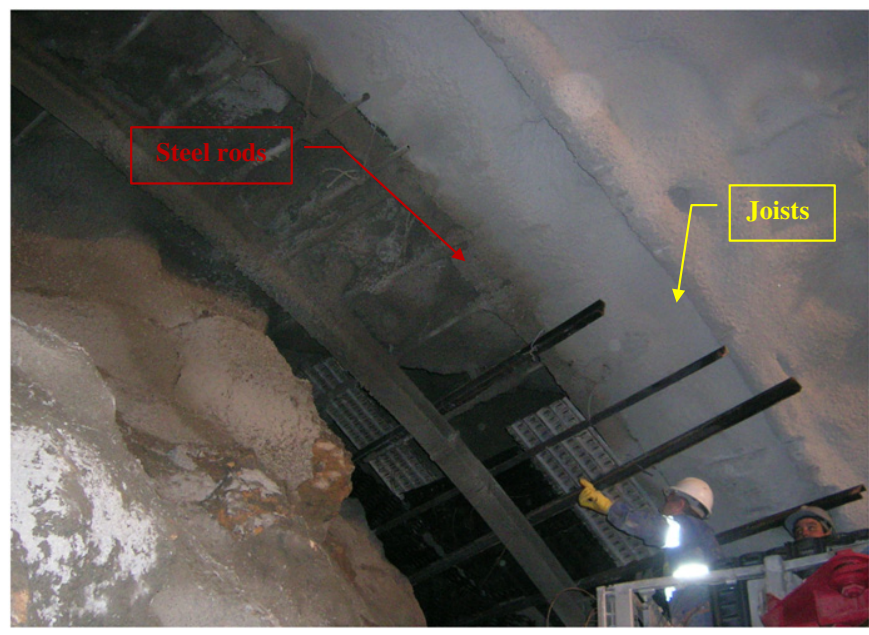

Fig. 4. Detail of the support with an umbrella of steel rods $4 \mathrm{~m}$ in length and packed with light beams.

decided to increase the number of the bolts and to raise their length from $4 \mathrm{~m}$ to $6 \mathrm{~m}$, overlapping $3 \mathrm{~m}$. Despite this reinforcement, masses of clay and limestone blocks were still able to strip out the bolts (Figure 5) requiring the improvement of the support solution. However, this light umbrella was used until section 80 where it was decided to place the first self-drilling heavy micropile umbrella, $12 \mathrm{~m}$ long and $90 \mathrm{~mm}$ in diameter, with an overlap of $3 \mathrm{~m}$ between umbrellas. From then on, the support with heavy umbrellas was used systematically. These umbrellas were made by approximately 35 micropiles, separated around $40 \mathrm{~cm}$ between their axes. The number of micropiles was dependent on the characteristics of the front at the time of excavation, and was decided according working crew's experience and to the technical assistance criteria.

- Zone 3 (section 91-235). In this zone of $163 \mathrm{~m}$ in length, the RMR values slightly increased, varying from 30 to 40 (class IV - bad). Many karstified rock masses appeared in the tunnel-working faces, causing several rockfalls, greater than those occurred up to this point. The geology is characterised by the dominance of limestone and clay. The limestone showed well-defined layers in the initial stretch of the zone, being more bulky and amorphous towards the final, turning difficult to disclose the orientations of $S_{0}, J_{1}$ and $J_{2}$. The uniaxial compressive strength presented an average of $32 \mathrm{MPa}$. The tunnel-working faces were dry and seemingly less fractured than in

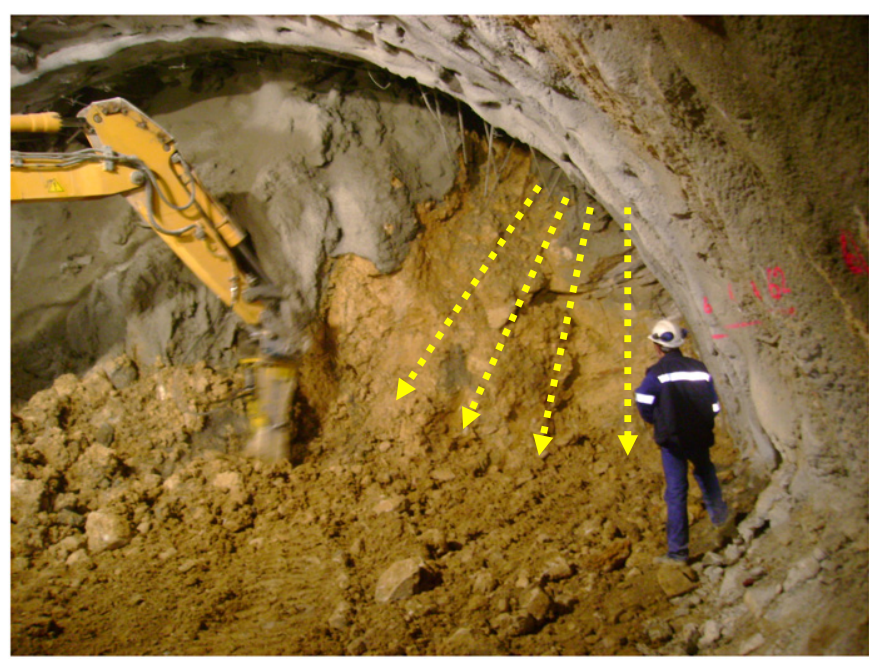

Fig. 5. View of an instability with a distorted light umbrella in Zone 2 (section 70). 
Zone 2. Fourteen convergence sections and one instrumentation cross-section were installed. Twenty engineering geology front maps were prepared. The measured strains showed tendency to stabilize, reaching maximum values under $5 \mathrm{~mm}$ in the convergence sections, while the extensometers measured up to $9.5 \mathrm{~mm}$ in the key during the advance. The pressure cells measured stresses from 0.05 to $0.1 \mathrm{MPa}$. The evidence of the effectiveness of the micropile umbrellas provided by the lower accumulated deformations, allowed the decision to switch to a lighter support, formed by TH-29 steel ribs (S-II). The advance speed of the tunnel increased up to $3.8 \mathrm{~m} /$ day due to the safety provided by the micropile umbrellas.

- Rockfall Zone (sections 235-463). This zone is characterised by a significant decrease of the RMR with values from 25 to 45 (poor quality, class IV), due to the presence of abundant damp spots, with some dripping being observed, and the decrease of the rock's uniaxial compressive strength to an average $27 \mathrm{MPa}$. The advance rate raised slightly to $4 \mathrm{~m} /$ day, due to the increased mastery of the working crew on placing the micropile umbrella. In this zone, two convergence sections were installed and six engineering geology cross sections of the tunnel face were mapped. The zone is composed of marly limestone materials without a clear arrangement, in which the joints are almost indistinguishable. Unlike the rest of the tunnel, here the damp spots increase, being observed some dripping and many karstification voids. Associated with the karst phenomena in this zone, several rockfalls occurred, even forcing to stop the work at chainage $501+462$, due to sudden, large rockfalls, requiring new work procedures.

A summary of the main characteristics of the tunnel zones previously described is presented in Table 4.

\section{The problems}

Since its beginning, the Gavarres tunnel presented a series of geotechnical complexities (rockfalls, detachments, over-excavations, etc.) that slowed down and hindered the excavation. These problems, related to karst phenomena (Ford and Williams, 1989), were not foreseen in the design.

The instabilities occurred during the excavation or support works, mainly in materials of brecciated aspect, consisting of boulders and blocks of limestone in a soft clay-marly matrix, which quickly collapsed or slide from the front, shoulders or crown of the tunnel. As the tunnel advanced, the presence of cavities, empty or partially filled by decalcification clays, became more frequent. These cavities

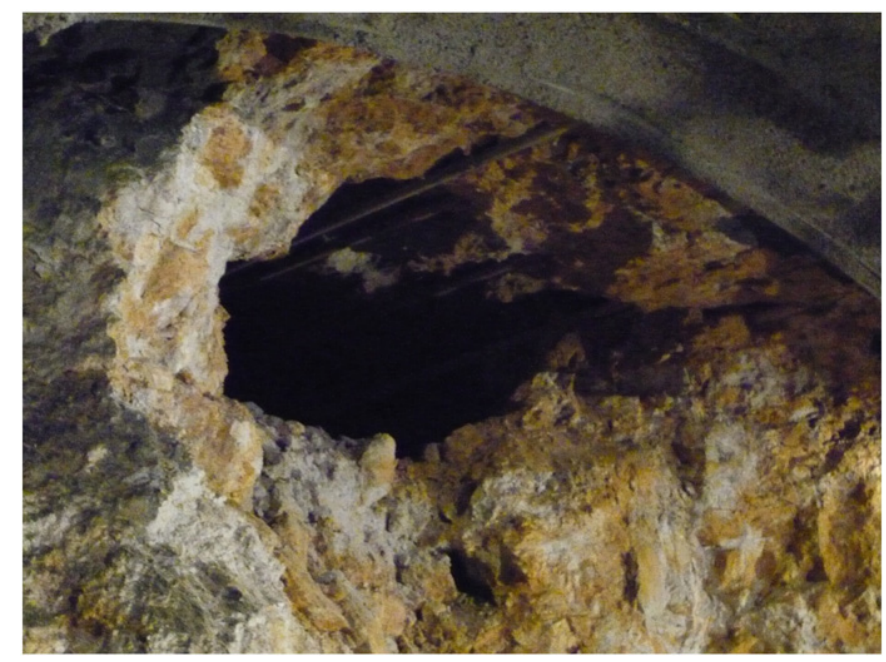

Fig. 6. View of a cavity of approximately $20 \mathrm{~m}^{3}$ affecting sections 206 to 210 .

(Figure 6) can also be problematic due to the absence of support between the tunnel lining and the ground, eventually causing problems throughout the lifetime of the tunnel.

Due to the poor geotechnical quality of the terrain, spiles and light micropile umbrellas were implemented but they were unable to stop the increase of the instabilities. For this reason it was decided to systematically use successive micropile umbrella $12 \mathrm{~m}$ long, overlapping $3 \mathrm{~m}$. With this solution gravitational instabilities still occurred, affecting the material that fell between the micropiles.

At dawn, on a normal work day on the Gavarres tunnel, a large instability hits the crown and right gable on section number 302 at chainage $501+462$ (Figure 7).

According to the description of the workers at that time inside the tunnel, the excavation round was running normally. After the excavation, the shotcrete sealing was applied and the steel rib was put in place; however, when the shotcrete robot was going into the front to finish the support, a rustle and a sudden break in the shotcrete sealing in the key and on the right side-wall zone occurred, followed by a slide of a large mass of clay and rock fragments into the tunnel. This slide gave sufficient time to workers to escape without personal injury.

On the next day it was found that the instability was constituted of limestone blocks and sharp edges, embedded in clay materials, typical

Table 4

Main characteristics of the tunnel zones.

\begin{tabular}{|c|c|c|c|c|c|}
\hline & Outlet Zone 1 & Zone 1 & Zone 2 & Zone 3 & Detachment zone \\
\hline Material & $\begin{array}{l}\text { Calcareous blocks in clay } \\
\text { matrix }\end{array}$ & $\begin{array}{l}\text { Calcareous blocks } \\
\text { in clay matrix }\end{array}$ & $\begin{array}{l}\text { Calcareous blocks in clay } \\
\text { matrix } \\
\text { G-III } \rightarrow \text { G-IV }\end{array}$ & $\begin{array}{l}\text { Initially calcareous blocks } \\
\text { and clay, clay masses at the } \\
\text { end }\end{array}$ & $\begin{array}{l}\text { Loamy-clay materials without clear } \\
\text { structure }\end{array}$ \\
\hline Structure & & $\mathrm{S}_{0}=195 / 14 \mathrm{~J} 1=$ & $215 / 74 \mathrm{~J} 2=127 / 76$ & & \\
\hline \multirow[t]{2}{*}{ Pass heading rate } & Pass $1 \mathrm{~m}$ & Pass $1 \mathrm{~m}$ & Pass $1 \mathrm{~m}$ & Pass $1 \mathrm{~m}$ & Pass $1 \mathrm{~m}$ \\
\hline & $4.6 \mathrm{~m} /$ day & $3.3 \mathrm{~m} /$ day & $3.18 \mathrm{~m} /$ day & $3.8 \mathrm{~m} /$ day & 4 m/day \\
\hline Water & Dry (occasional damp spots) & Frequent spots & Abundant moisture & Dry fronts and less fractured & Abundant damp spots and drips \\
\hline RCS & & $44 \mathrm{MPa}$ & $34 \mathrm{MPa}(\downarrow)$ & $32 \mathrm{MPa}(\downarrow)$ & $28 \mathrm{MPa}$ \\
\hline Support & S-E & S-III' & S-III' & S-III' $\rightarrow$ SII $^{\prime}$ & $\mathrm{SII}^{\prime}$ \\
\hline Convergences' & A-B: $8-11$ & A-B: $3-5$ & A-B: $1-9$ & A-B: $0-2$ & - \\
\hline $\begin{array}{l}\text { maximum } \\
\text { shortening }(\mathrm{mm})\end{array}$ & $Z: 3-17$ & $\mathrm{Z}: 3-4$ & $\mathrm{Z}: 0-4$ & $\mathrm{Z}: 0-5$ & \\
\hline Monitoring sections & - & - & - & $\begin{array}{l}0.05 \mathrm{MPa} \\
\mathrm{A} \rightarrow 10 \mathrm{~mm} \\
\mathrm{D} \rightarrow 17 \mathrm{~mm}\end{array}$ & - \\
\hline Excavation & Regular mechanical & $\begin{array}{l}\text { Mechanical and } \\
\text { specific blasting }\end{array}$ & Regular mechanical & Easy mechanical & Easy mechanical \\
\hline Observations & $\begin{array}{l}\text { Small detachments of } \\
\text { calcareous blocks embedded } \\
\text { in clay matrix }\end{array}$ & $\begin{array}{l}\text { Cavities from the } \\
\text { karstification } \\
\text { processes }\end{array}$ & $\begin{array}{l}\text { Vey karstified fronts, and } \\
\text { broken up by frequent } \\
\text { detachments }\end{array}$ & $\begin{array}{l}\text { Increased instability caused } \\
\text { by karstification. Large } \\
\text { detachments }\end{array}$ & $\begin{array}{l}\text { Very frequent detachments and } \\
\text { holes. Stop the tunnel in drive (large } \\
\text { detachment) }\end{array}$ \\
\hline
\end{tabular}




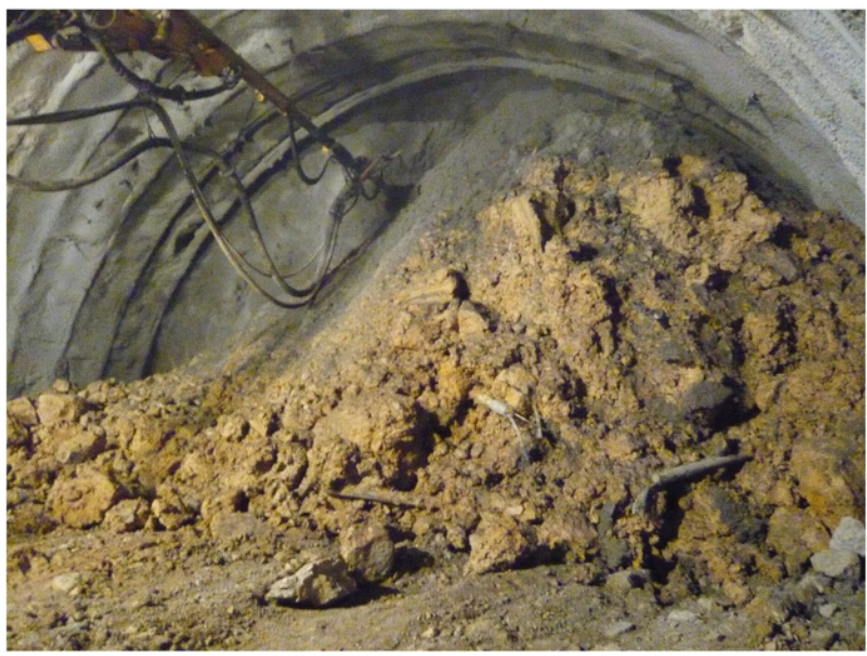

Fig. 7. View of the large instability affecting section 302, obliging to stop the work in the tunnel.

of the decalcification processes with high humidity. The volume of material introduced into the tunnel was about $200 \mathrm{~m}^{3}$ and left no visible cavity. The fallen material formed a "stable" cone of loose material, which occupied most of the excavated section, sustained and stopped a larger amount of material, as it was evident that the cavity above the tunnel was not emptied. The visible consequences were the breaking of a large number of micropiles and the deformation of the last steel rib. Once the fallen material was excavated, the gap was sealed and the deformed steel rib was replaced.

The stability problem appeared to be due to a gravitational collapse on the front and crown, of deposits associated with karst phenomena. Later on, several dolines (sinkholes) were identified at the ground surface above the failure. As observed, the deposits associated with karst phenomena, due to their low cohesion and strength, frequently cause instabilities when traversed by a tunnel (Jianjy and Jian, 1987).

\section{Causes and possible explanations}

After the failure previously described, which obliged to stop the tunnel works, new geological studies were done, based on the information obtained during the excavation and support of the tunnel. These studies allowed the reinterpretation of the geology of the area, helping to explain the abundance of karst phenomena not previously identified during the design.

In this new interpretation, it was concluded that the tunnel instability occurred in the Girona Fossiliferous Limestone Formation and not in the Banyolas Limestone Formation. The fossiliferous limestone of the Girona Formation is more susceptible to karst phenomena in zones of intense tectonic fracturing, like the one in which the tunnel was being dug.

The main causes that led to this interpretation error were the following:

- a diffuse contact between the two geological formations (interdigitations);

- abundant vegetation;

- absence of outcrops.

The failures could thus be mainly attributed to the presence of zones of high geotechnical complexity related to tectonic and karst phenomena.

\section{Solutions and recommendations}

The rock mass can be described as brecciated with significant karstification of the limestone. The presence of empty or partially filled cavities, with silty and sandy clay deposits of low cohesion, is common. Under these conditions it is difficult, with the usual procedures of excavation and support, to ensure the stability of the excavation without causing major instabilities given the loose nature of the materials' filling cavities and fractures. For initial containment, spiles with light beams and bolt umbrellas were used. As the volume of the unstabilized materials increased, a systematic use of heavy micropile umbrella became necessary. However, the heavy micropile umbrella proved to be insufficient when crossing large cavities filled with soils. Considering all the problematic situations previously described, it became necessary to define new working procedures for the construction of the tunnel, to suitably deal with the karstified terrain characteristics and to seek the increase in safety and construction efficiency.

It is important to highlight that the karst phenomenon is one of the most difficult problems to solve in the advance front of a tunnel, due to the great diversity of circumstances that may come up, and especially because of the variability of their occurrence. This is due to the erratic development of the dissolution processes, to the multitude of associated phenomena and to their influence on stability, depending on the rock mass characteristics in which the karst developed.

The treatment procedures described below, in incremental sequence of complexity, were considered appropriate for dealing with each instability situation, and adjusted to the specific geotechnical characteristics of the terrain traversed by the tunnel. Note that the following ground treatment procedures should be added to those previously described for the general support of the tunnel:

- Case 1: Good geotechnical characteristics. This is the most favourable situation in which the traversed ground starts to show signs of karstification, generating a negligible impact on the implementation of the tunnel. The limestone massif is stable and slightly weathered. Small cavities in the side-walls or in the crown may be filled with shotcrete, assisted by the use of Bernold sheets as permanent formwork. In this case there would hardly be any instabilities or detachment of material into the excavated tunnel.

- Case 2: Good to fair geotechnical characteristics. It can be found in zones with low to medium karstification, with presence of decalcification clay, filling some cavities, and would not produce significant detachments. If instabilities would develop in the side-walls, it should be sufficient to stabilize the cavities, to do dental cleaning of the clay materials, and fill the voids with shotcrete or pumped lean concrete, and eventually use Bernold plates as permanent formwork. In the crown it may be necessary to use self-drilling anchors as pre-support, to ensure safety. In this situation the cavities should also be filled with shotcrete or lean concrete.

- Case 3: Fair geotechnical characteristics. The limestone rock mass is fairly weathered, presenting large cavities filled by moderately cohesive materials, generating small detachments due to the deconfinement. The volume and weight of this fill can overcome the strength of the rock bolts, not guaranteeing the safety of the excavation. For this zone, it would be appropriate to adopt the use of heavy micropile umbrella $12 \mathrm{~m}$ long, spaced $40 \mathrm{~cm}$ between axes (considering the micropile diameter around $90 \mathrm{~mm}$ ), with an overlap of 3-4 m and adjusting the dimensions to suit each problem detected. The micropiles have high rigidity and high capacity to withstand the loads from detachments of loose ground that may occur on the edge of the section. The use of heavy steel ribs (HEBs) would improve the support of the umbrella due to its high rigidity, helping to absorb local loads. In the event that during the implementation of the first phase of the umbrella no significant anomaly is detected, the injection of the tubes in a single phase and through their mouth should be done. 
- Case 4: Fair to poor geotechnical characteristics. If during the implementation of the micropile umbrella from the previous case, zones of intense fracturing, filled cavities with soft material or empty voids, are detected, a second phase of micropiles in the arch of the umbrella (spaced $25 \mathrm{~cm}$ between axes) should be inserted. This previous procedure should also be used when, in the first phase of the umbrella, the grout injection pressure can't be raised, indicating an uncontrolled admission of grout. The number and location of alternating micropiles will depend on the spatial distribution of unstable areas along the tunnel. The placement of a "temporary" steel rib to support the first metre of the heavy umbrella is advisable. The alternating micropiles in this second stage should be equipped with two unidirectional valves (at $180^{\circ}$ ) with a diameter of 10 to $12 \mathrm{~mm}$, located along the tube and spaced one meter between consecutive drills, allowing localized injections along the micropile tube.

- Case 5: Poor geotechnical characteristics. When, during the implementation of the micropiles, the ground mass worsens considerably, due to karst phenomena, it will be necessary to inject grout through the micropile valves of the second phase. In this case the injection may need to be done with the use of shutters, in order to distribute as evenly as possible, the flow of grout along the micropile. This procedure creates a reinforced injection umbrella. The injection intends to fill the empty cavities close to the crown of the tunnel and, when the cavities are filled with soil, to improve their properties. It creates an injected ground crown between the micropiles, which significantly increases safety during the excavation and supports works. Subsequently the grout injection of the micropiles from the first phase should be undertaken.

- Case 6: Very poor geotechnical characteristics. In this case, the ground mass would generally be very unstable, and the above procedures will not guarantee the safety of the work in the tunnel. In this case the pre-support techniques become ineffective and it is necessary to do systematic ground treatment around the excavated section. To increase the stability conditions of the ground mass, improving its mechanical characteristics, either the injection of high cohesion products (cement grout or resin) or jet grouting treatments could be used. This last option is the most difficult to implement, because the equipment required is highly specific and the construction procedures necessary to carry out the treatment are complex. However, if necessary, this treatment would allow to solve the problem by creating a series of horizontal columns of reinforced ground around the section to be excavated.

- Case 7: Empty cavities and landslides. When there is admission of grout without the rise in pressure, in a specific part of the micropile, this zone should be interpreted as a cavity. In the event that a cavity is detected in the first six meters, the umbrella may be considered to have a "bridge" type effect, and the top heading must be planned to reach, or even surpass, the cavity zone. If the cavity is located in the second half of the umbrella, having a length of about two or three meters, it may be considered that the protection provided by the umbrella would not be guaranteed, thus being ineffective. In this case, the previous fill of the cavity would be necessary. Among the materials that can be used to fill a cavity, are: lean concrete, mortar, resins, polyurethane or grout. It is advisable to use the cheapest material because the volumes to be filled may be huge. In the case where a particular fill area or cavity is identified in several consecutive micropiles within an umbrella, it might be advisable to drill 2 or 3 bores in the front, in order to define the limit of the fill area, and act on it. The presence of a filled volume that can be suddenly emptied near the upper contour of the tunnel may excessively increase the free span of the umbrella, causing its deformation. In this case, the objective of the treatment is to stabilize the fill. The process would be similar to the one proposed for the umbrellas, taking into account that in this case the treatment must be compatible with the subsequent excavation. If an empty cavity appears in the side-walls of the tunnel, its effect would not be as great as in the case of the umbrella.
In the case of intersecting a cavity filled with water, the only possibility is to drain it.

The seven cases described above are summarised in Table 5.

To reduce the uncertainty about the grade of karstification of a limestone rock mass, in which a tunnel is to be constructed, the use of geophysical prospection techniques is highly recommended (Richter et al., 2008). Electrical tomography is especially useful to determine the spatial distribution of the ground resistivity, to locate discontinuities or different terrain characteristics (faults, lithological contacts, cavities, clay fillers, bedding planes, etc.).

During construction, the reconnaissance shall continue with horizontal borings in the excavation front, or by monitoring the drillings made from the interior of the tunnel (drill holes, micropiles, etc.). The use of modern TSP seismic systems can also be useful, allowing analysing the propagation of the seismic waves from the inside of the tunnel towards the advancing front. As a long-term stability procedure, it is advisable to prevent the presence of voids close to the lining of the tunnel. A quick and efficient way to assess for the presence of voids behind the tunnel support is to use the georadar.

Table 5

Summary of special treatment procedures proposed for karstified zones of the Gavarres tunnel.

\begin{tabular}{|c|c|c|c|c|}
\hline Case & Type & Description & $\begin{array}{l}\text { Pre-support } \\
\text { treatment }\end{array}$ & $\begin{array}{l}\text { Improvement } \\
\text { treatment }\end{array}$ \\
\hline 1 & $\begin{array}{l}\text { Site with good } \\
\text { geotechnical } \\
\text { characteristics }\end{array}$ & $\begin{array}{l}\text { Slightly karstified } \\
\text { limestone massif. } \\
\text { Small cavities }\end{array}$ & $<>$ & $\begin{array}{l}\text { Fill cavity with } \\
\text { gunite. Use of } \\
\text { Bernold sheets }\end{array}$ \\
\hline 2 & $\begin{array}{l}\text { Site with good } \\
\text { regular } \\
\text { geotechnical } \\
\text { characteristics }\end{array}$ & $\begin{array}{l}\text { Massif with little } \\
\text { karstification, } \\
\text { with cavities of } \\
\text { certain body } \\
\text { (filled or not) }\end{array}$ & $\begin{array}{l}\text { Light bolt } \\
\text { umbrella }\end{array}$ & $\begin{array}{l}\text { Fixing and filling } \\
\text { the cavities with } \\
\text { gunite or lean } \\
\text { concrete. }\end{array}$ \\
\hline 3 & $\begin{array}{l}\text { Site with } \\
\text { regular } \\
\text { geotechnical } \\
\text { characteristics }\end{array}$ & $\begin{array}{l}\text { Moderately } \\
\text { karstified massif. } \\
\text { Frequent large } \\
\text { cavities. Frequent } \\
\text { landslides. }\end{array}$ & $\begin{array}{l}\text { Micropile } \\
\text { umbrellas of } 90 \text {, } \\
12 \mathrm{~m} \text { long and } \\
\text { spaced } 40 \mathrm{~cm} \\
\text { from the axis and } \\
\text { with an overlap of } \\
3 \mathrm{~m} \text { (phase } 1 \text { ) }\end{array}$ & $<>$ \\
\hline 4 & $\begin{array}{l}\text { Site with } \\
\text { regular poor } \\
\text { geotechnical } \\
\text { characteristics }\end{array}$ & $\begin{array}{l}\text { Moderately } \\
\text { karstified massif } \\
\text { with located } \\
\text { detachments and } \\
\text { soils flows in } \\
\text { favour of cavities } \\
\text { between } \\
\text { micropiles }\end{array}$ & $\begin{array}{l}\text { Micropile } \\
\text { umbrellas of 90, } \\
12 \mathrm{~m} \text { long and } \\
\text { spaced } 25 \mathrm{~cm} \\
\text { from the axis and } \\
\text { with an overlap of } \\
3 \mathrm{~m} \text { (phase 2) }\end{array}$ & $<>$ \\
\hline 5 & $\begin{array}{l}\text { Site with poor } \\
\text { geotechnical } \\
\text { characteristics }\end{array}$ & $\begin{array}{l}\text { Very weathered } \\
\text { massif. Unstable } \\
\text { ground and } \\
\text { loosely cohesive } \\
\text { with significant } \\
\text { landslides. }\end{array}$ & $\begin{array}{l}\text { Micropile } \\
\text { umbrellas of 90, } \\
12 \mathrm{~m} \text { long and } \\
\text { spaced } 25 \mathrm{~cm} \\
\text { from the axis and } \\
\text { with an overlap of } \\
3 \mathrm{~m} \text { (phase 2) }\end{array}$ & $\begin{array}{l}\text { Injection of grout } \\
\text { or mortar through } \\
\text { the values of the } \\
\text { micropiles of } \\
\text { phase } 2 \text { (armed } \\
\text { injection) }\end{array}$ \\
\hline 6 & $\begin{array}{l}\text { Site with very } \\
\text { poor } \\
\text { geotechnical } \\
\text { characteristics }\end{array}$ & $\begin{array}{l}\text { Very karstified } \\
\text { massif. Highly } \\
\text { unstable and } \\
\text { unsafe terrain. } \\
\text { Ineffectiveness of } \\
\text { the pre-support } \\
\text { treatments. }\end{array}$ & $<>$ & $\begin{array}{l}\text { Injection of high } \\
\text { cohesion products } \\
\text { or soil } \\
\text { improvement by } \\
\text { replacement (jet } \\
\text { grouting) }\end{array}$ \\
\hline 7 & $\begin{array}{l}\text { Empty } \\
\text { cavities and } \\
\text { Landslides }\end{array}$ & $\begin{array}{l}\text { Detection of areas } \\
\text { with cavities, } \\
\text { cavities generated } \\
\text { by landslides or } \\
\text { fallen debris } \\
\text { produced by } \\
\text { landslides }\end{array}$ & $<>$ & $\begin{array}{l}\text { Consolidation } \\
\text { injections and } \\
\text { filling cavities. Use } \\
\text { of lean concrete, } \\
\text { mortar, synthetic } \\
\text { resins or grout. }\end{array}$ \\
\hline
\end{tabular}




\section{Conclusions}

In the Gavarres tunnel, the problems reported were mainly caused by unsuitable ground behaviour, due to karstification and to the heterogeneous and unpredictable limestone rock mass, corresponding to geotechnical zones of very poor quality. The reduced cohesion and unsuitable geomechanical characteristics of the soils filling the karst cavities generated serious instability problems and thus, the procedures initially proposed for the tunnel excavation and support were not able to ensure a safe construction. Despite the problems reported, the deformations generated by tensions were irrelevant.

Due to partial or total excavation of the tunnel section, landslides and emptying of karst cavities filled with soils begun to develop. The presence of medium size blocks (even metric) of limestone embedded in the filler soils favours the collapse due to their own weight, detaching and dragging the materials of worse competence.

The early detection of karstified zones during site investigation allows defining adequate design and construction procedures, towards a successful excavation and support. A correct geologic characterisation of the ground mass and the combined use of mechanical site investigation techniques with geophysical techniques (seismic, electrical tomography, georadar, etc.) are of vital importance.

The use of pre-support of the section to be dug (bolts, micropiles, etc.) and of ground improvement techniques in the edge of the excavation (injections, backfilling, partial substitutions, etc.) proved to be highly efficient. Using this approach, personal injuries and/or economic losses related to the stoppage of the construction work or the need to redefine the excavation and support procedures during construction can be avoided.

The solutions and recommendations presented here may provide guidance for the study, design and construction of tunnels to be implemented in rock masses affected by karst processes. The technical validation of the proposed solutions was demonstrated by the successful completion of the Gavarres tunnel.

\section{References}

Agustí, J., Berástegui, X., Llenas, M., Losantos, M., Mató, E., Picart, J., Saula, E., 1994. Evolución Geodinámica de la Fosa del Emporda y las Sierras Transversales. Acta Geologica Hispánica 29 (2-4), 55-75 (in Spanish).

Alija, S., 2010. Análisis retrospectivo sobre la problemática de túneles ejecutados en rocas blandas. Philosophical Thesis. Department of Earth Engineering, Universidad Politécnica de Valencia, Spain (in Spanish).

Anguita, F., Moreno, F., 1993. Procesos geológicos externos y geología ambiental. Rueda, Madrid, Spain 311 (in Spanish).

Barton, N., Lien, R., Lunde, J., 1974. Engineering classification of rock masses for the design of tunnel support. Rock Mechanics 6 (4), 189-236.

Bieniawski, ZT, 1989. Engineering Rock Mass Classifications. A Wiley-Interscience, USA

Díaz, B., 1997. Clasificación de los Terrenos según su Excavabilidad. Ch. 5 In: López Jimeno, C. (Ed.), Manual de Túneles y Obras Subterráneas. Entorno Gráfico, S.L., Madrid, pp. 183-211 (in Spanish).

Ford, D., Williams, P., 1989. Karst Geomorphology and Hydrology. Unwin Hyman, Great Britain.

González de Vallejo, L.I., Ferrer, M., Ortuño, L., Oteo, C., 2002. Ingeniería Geológica. Pearson Education, Madrid (744 p., in Spanish).

Hoek, E., Brown, E.T., 1980. Underground Excavations in Rock. The Institution of Mining and Metallurgy, London.

Hoek, E., Kaiser, P.K., Bawden, W.F., 1995. Support of Underground Excavations in Hard Rock. Balkema, Rotterdam.

IGME, 1983. Mapa Geológico de España. Escala 1:50.000. Hoja 296. "Torroella de Montgri". Madrid (in Spanish).

IGME, 1995. Mapa Geológico de España. Escala 1:50.000. Hoja 295. “Banyoles”. Madrid (in Spanish).

ISRM, 1981. Description of rocks masses. International Journal of Rock Mechanics and Mining Sciences 18, 85-110.

Jianjy, T., Jian, C., 1987. Preliminary Study of Karst Collapse. Forecast Method. Endins, no 13-1987 (Palma de Mallorca).

López, C., 1996. Manual de Túneles y Obras Subterráneas. Entorno Gráfico, Madrid (1080 p, in Spanish)

Richter, T., Dieter Kirschke, D., Manfred Jäkel, M., 2008. Geophysical investigations in advance and of the surrounding karstified rock during the construction of the "Katzenberg Tunnel" in Germany. Geomechanics and Tunnelling 1 (5), 450-459. 